\title{
ASSESSMENT OF VEGETATION COVER STATUS IN DRY LANDS OF THE SUDAN USING SOCIAL AND TERRESTRIAL DATA
}

\section{MOHAMMED HAMED MOHAMMED ${ }^{1 *}$, SUZAN ABDELRAHMAN HAMAD ${ }^{2}$, \& HASSAN ELNOUR ADAM ${ }^{1}$}

\author{
${ }^{1}$ Department of Forestry and Range Sciences, Faculty of Natural Resources and Environmental Studies, \\ University of Kordofan, 51111 Elobeid, Sudan \\ ${ }^{2}$ Forests National Corporation, North Kordofan, Sudan \\ *Email: hamed1705@yahoo.com
}

\begin{abstract}
The current study was conducted in 2015 in Bara Locality, North Kordofan, Sudan. The study area has experienced recurrent drought spells since 1970s of the past century. The main objective of this study was to assess and map the vegetation cover in the area using social, terrestrial and remotely sensed data. To accomplish the above mentioned objective, the study was based on qualitative and quantitative data. In qualitative data, household survey was conducted in which 100 respondents were randomly interviewed. Quantitative data was collected using terrestrial inventory and satellite imageries. In terrestrial inventory, 22 ground control points (GCPS) were randomly registered using GPS in order to get general overview of the land cover of the study area. In each GCP, tree species by number was inventoried within an area of 1 ha. Remote sensing data, covering the target study area, were acquainted using LANDSAT5 imageries (2014) with spatial resolution of $30 \times 30 \mathrm{~m}$. Results of the household survey revealed that only 13 shrub/tree species mentioned by $45 \%$ of the respondents, while only 9 woody species were identified, belonging to 8 families from terrestrial inventory. The results of the household survey, $45 \%$ of the respondents, indicated that vegetation cover was very good 20 years ago. The study categorized the present land cover as woody vegetation (19\%), Acacia senegal stands (5\%), shrubs i.e. Leptadenia pyrotechnica and Acacia nubica (18\%), small scale farms and grasses (19\%) and sandy soil and dunes (39\%). The results of the land cover distribution indicated that vegetation cover decreased by 24\% while sand/sand dunes was increased by 21\% from 1985 to 2015. The study concluded that the study area is under threat of land degradation that may lead to depletion of vegetation cover and decline land productivity.
\end{abstract}

Keywords: Acacia senegal, land cover, remote sensing, sand dune, Sudan.

\section{INTISARI}

Penelitian ini dilakukan pada tahun 2015 di Lokalitas Bara, Kordofan Utara, Sudan. Lokasi penelitian telah mengalami masa kekeringan yang berulang sejak dekade 1970-an. Tujuan utama dari penelitian ini adalah untuk menilai dan memetakan tutupan vegetasi di lokasi penelitian dengan menggunakan data sosial, terestrial, dan penginderaan jauh. Untuk mencapai tujuan dimaksud, penelitian ini menggunakan data kualitatif dan kuantitatif. Untuk data kualitatif, survei rumah tangga dengan wawancara terhadap 100 responden yang dipilih secara acak. Data kuantitatif dikumpulkan dengan menggunakan inventarisasi terestrial dan satelit citra. Untuk inventarisasi terestrial, 22 titik kontrol (GCP) didaftar secara acak dengan menggunakan GPS untuk mendapatkan gambaran umum dari tutupan lahan daerah penelitian. Pada setiap $G C P$, jumlah spesies pohon diinventarisasi dalam area 1 ha. Data penginderaan jauh yang mencakup wilayah studi diambil dengan citra LANDSAT5 (2014) dengan resolusi spasial $30 \times 30 \mathrm{~m}$. Hasil survei rumah tangga 
menunjukkan bahwa hanya 13 jenis semak/pohon yang disebutkan oleh 45\% responden, sementara hanya 9 spesies kayu yang terindentifikasi, milik 8 keluarga dari inventarisasi terestrial. Berdasarkan hasil survei rumah tangga, 45\% dari responden menyatakan bahwa tutupan vegetasi yang sangat baik 20 tahun yang lalu. Penelitian ini mengelompokkan tutupan lahan saat ini ke dalam vegetasi berkayu (19\%), tegakan Acacia senegal (5\%), semak yaitu Leptadenia pyrotechnica dan Acacia nubica (18\%), pertanian skala kecil dan rerumputan (19\%), dan tanah dan bukit pasir (39\%). Hasil dari distribusi tutupan lahan menunjukkan bahwa tutupan vegetasi mengalami penurunan sebesar 24\%, sedangkan proporsi pasir/bukit pasir meningkat 21\% dari 1985 ke 2015. Penelitian ini menyimpulkan bahwa daerah penelitian berada di bawah ancaman degradasi lahan yang dapat menyebabkan penipisan vegetasi tutupan dan menurunkan produktivitas lahan.

Kata kunci: Acacia senegal, tutupan lahan, penginderaan jauh, bukit pasir, Sudan.

\section{INTRODUCTION}

Land degradation has been recognized as a global problem associated with desertification and loss of biological diversity, particularly in drylands (Kellner et al., 2011). Drylands occupy $41 \%$ of Earth's land area in which $10-20 \%$ of them are already degraded and $1-6 \%$ of the dryland people live in desertified areas (Millennium Ecosystem Assessment, 2005). Vegetation cover is considered one of the most commonly indicator used to assess terrestrial ecosystems and to evaluate land degradation and recovery (Godinez-Alvarez, 2009).Vegetation cover is considered as an important component of the drylands ecosystem that necessitates better understanding of its change (IPCC, 2001). Hence, detection of vegetation cover change in drylands and understanding of its causes and consequences depend on the vegetation assessment (Sillivan and Rohde, 2002).

Condition and type of vegetation cover are important aspects of land cover change for sustainable natural resources management. To do so, vegetation cover assessment has to be done through one or combination of various methods to quantify degradation process. The main objective of vegetation cover assessment is to detect changes over time due to land use patterns. Several methods have been used to assess vegetation cover. Based on the purpose of vegetation or biodiversity assessment, Lee et al. (2005) recognized five methods of monitoring, these are; management inventory/ monitoring, general habitat inventory, status and trend monitoring, surveillance monitoring and research monitoring. Recently, remote sensing technique has been used widely to support other methods in assessing vegetation cover as it considered an efficient tool to investigate human induced changes in land cover and land use (Kumpula et al., 2012).Land-use and land-cover charge associated with agricultural expansion and intensification is the most visible indicator of the human footprint on the biosphere (Gardner et al. 2013). Remote sensing technique is considered a suitable tool for observing vegetation cover change as it provides cost-effective information that plays a useful role in understanding the nature of changes in land cover and at the same time essential for natural resource planners and decision makers (Squires, 2010).

In this study, social and terrestrial data were integrated to assess vegetation cover with special reference to tree cover in Geraigikh Administrative at Bara Locality, North Kordofan-Sudan. Combined method between social survey and terrestrial data for 
vegetation cover assessment was applied by many authors (e.g. Chalmers and Fabricius, 2007; Ibrahim, 2013; Khiry, 2007; Khiry et al. 2014). Huntington (2000) noted that the traditional ecological knowledge (TEK) or social survey provides insight knowledge, from resourced users, to understand and predict environmental events upon which the livelihood or even survival of the individual depends.

According to Sudan National Adaptation for Action, NAPA (2007), the western parts of Sudan and Kordofan in particular, have experienced recurrent drought spells since 1970s of the last century. As noted by Elasha (2006) two types of drought, with varying severity, have affected Sudan. The first, widespread drought is caused by below normal rainfall across the country; the second is localized drought that affects only some parts of the country like Kordofan and Darfur. She further noted that recurrent series of dry years have become normal phenomena in the Sudano-Sahel region, especially in North Kordofan. Consequently, desertification and desert encroachment have threatened thousand hectares which once upon a time considered as productive areas as far as crops, trees, rangelands and biodiversity aspects are concern. The main objective of this study was to assess the vegetation cover status in the area using social survey and temporal data acquired from LANDSAT5 imageries in 1985 and 2015.

\section{MATERIALS AND METHODS}

\section{Study Area}

The current study was carried out in Gireigikh Administrative at Bara Locality which is situated at the north eastern part of North Kordofan State between latitudes $13^{\circ} 34^{\prime}$ to $14^{\circ} 47^{\prime} \mathrm{N}$ and longitudes $30^{\circ} 5^{\prime}$ to $31^{\circ} 47^{\prime}$ E covering an area of about 11850 $\mathrm{km}^{2}$ (Fig. 1). The climate of Bara Locality as described by Elasha et al. (2008) is semi arid, average annual rainfall is quite low $250-300 \mathrm{~mm}$ with high seasonal and interannual variability. Undulating surface of poor sandy soils and sand dunes with some pockets of clay are the prominent feature of the locality. Vegetation cover can be describes as poor range lands and scatter woody plants dominated by Acacia tortilis, Leptadena pyrotechnica, and Acacia senegal.

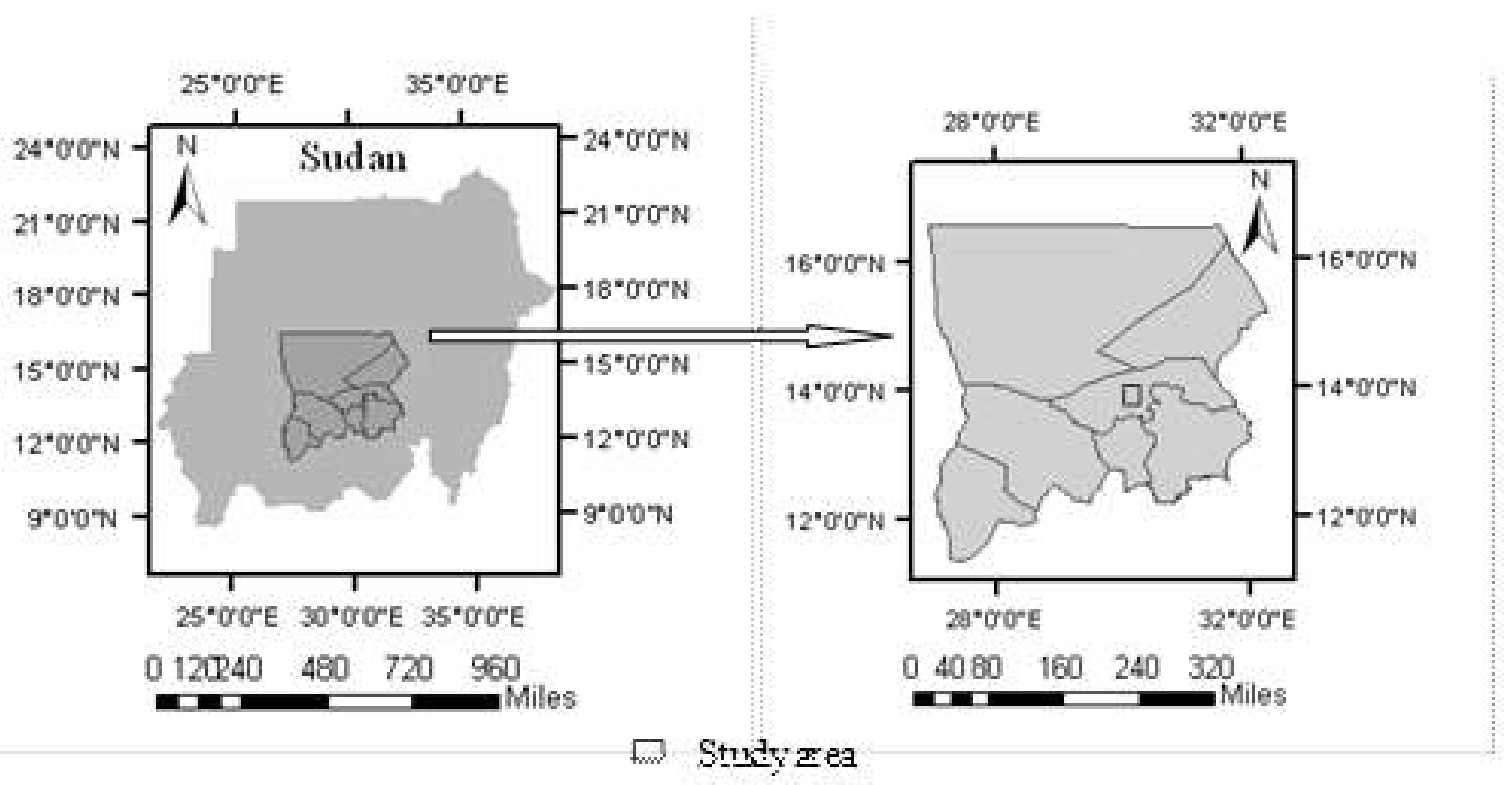

Figure 1. Location of the study area, Geraigikh Administrative in Bara Locality, North Kordofan-Sudan. 


\section{Data Collection and Analysis}

The study was based on qualitative and quantitative data to accomplish the above mentioned objective. In qualitative data, household survey was conducted in which 100 respondents were randomly interviewed on issues related to vegetation cover past and current status in the area. The house field survey was supported by key informant questionnaire in order to provide insight data and confidential information that may not be obtained by household field survey (Kumar, 1989).

Quantitative data was collected using terrestrial inventory and satellite imageries. In terrestrial inventory, 22 ground control points (GCPs) were randomly recorded using GPS in order to get general overview of the land cover of the study area. In each GCP, tree species by number was inventoried within an area of 1 ha. The suitable period for satellite data collection to interpret forested areas in Sudan is the dry season with cloud free conditions from October May (Adam, 2011; Wallace and Furby, 1994). Accordingly, imageries for the current study were acquired representing two dates from TM landsat5 (dated 12.01.1985) and TM landsat 8 (dated 20.03.2015) with spatial resolution of $30 \times 30 \mathrm{~m}$ and covering two scenes (174/50 and 174/51). The mosaic imageries were geo-referenced to the WGS84 datum and Universal Transverse Mercator (UTM) projection. A subset from each mosaic image covering an area of 29978.96 ha was created. Visual interpretation was conducted to satellite imageries and comparing the features with their in-situ characteristics in the study area. The GCPs were used for creating training fields to support supervised classification using maximum likelihood method based on Mather and Brandt (2009). Representative training data for each predefined classes was used in the supervised classification. The obtained data was subjected to analysis using Statistical Package for Social Science (SPSS) and Microsoft Excel. Additionally, ERDAS Imagine 9.1 was used for imagery pre-processing, processing and classification. Parameters calculated for the vegetation cover included species frequency (F\%) and abundance using the following formulas:

Frequency Percent $(F \%)=$

Number of plots in which the species ocurred Total number of plots surveyed $X 100 \%$

Abundance $=$

Total number individuals of a species in all plots

Total number of plots in which the species ocurred

\section{RESULTS AND DISCUSSION}

\section{Vegetation Cover Status and Trend Based on Respondents' Viewpoint}

Respondents, as resource users, are aware with the status of vegetation cover in the study area whether it is developing or deteriorating. More than twenty percent of the respondents declared that vegetation cover in the study area is developing while $58 \%$ of the respondents were indicated that vegetation cover is deteriorating (Fig. 2). In this context, respondents could identify six factors that lead to deterioration of vegetation cover. Among them are erratic low rainfall, overgrazing and overcutting. However, four reasons e.g. protection, projects intervention, seed broadcasting and grazing system were acknowledged by respondents to have considerable contribution in improving vegetation cover. The results of the household survey, $45 \%$ of the respondents, indicated that vegetation cover was very good before 20 years. On average, more than $70 \%$ of the respondents see the current situation is better than before and the landcover is considered good (Table 1). The respondents' judgment about the land cover situation depends on their general 
observation in a particular area without real assessment which may consider a subjective tool for assessment. Results obtained from household survey indicate that respondents prefer to plant a certain tree species such as Acacia senegal and Ziziphus spina-christi in their farm lands while Azadirachta indica in their homelands. The main reason behind planting such (multi-purposes tree species) is to provide non-timber forest products (NTFPs) such as gum and fruits as well as fire-wood and building poles. Other reasons were that those tree species require low-input technologies and less labor compared to agricultural crops (Glover, 2005).

\section{Species Diversity and Abundance}

Results of the household survey revealed that only $13 \mathrm{shrub} /$ tree species mentioned by $45 \%$ of the respondents, while only 10 and 12 of woody and grass species, respectively, were identified during terrestrial inventory with average abundance of 47 stems (Table 2). Species that had the highest frequency percent included Leptadenia pyrotechnica (85.7\%) and Acacia tortilis (81\%) with relative abundance of 35 and 37.8, respectively (Table 2). While understory vegetation, Aristida spp., Eragorostis termula and Cenchrus spp. have scored the highest frequency percent, 95, 95 and 67, respectively. Generally, the study area is considered poor in terms of species diversity since it accommodates only 9 species. All species enumerated during the field survey,with exception to Hyphaene thebaica $(\mathrm{F} \%=0.19$; abundance 9.3),were already reported in previous survey conducted by GEF (1994). The presence of Hyphaene thebaica could be attributed to the new plantation for providing saaf (leaves of Hyphaene thebaica) for women to produce handcrafts. The ten tree/shrub species encountered in the study was not different than 11 species enumerated by GEF (1994) in the same area. However, the average abundance (only 47 stems) was less than 280 stems during the

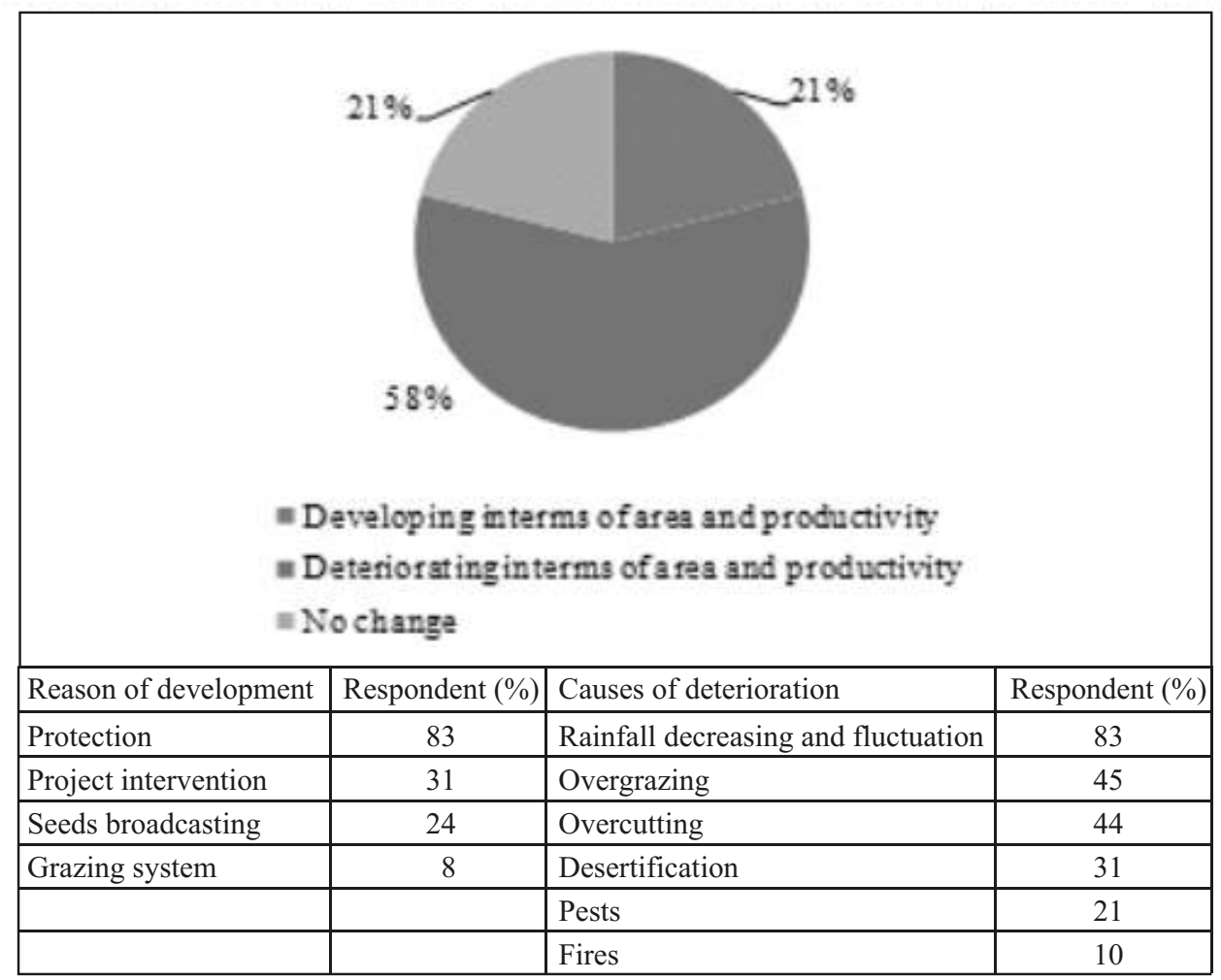

Figure 2. Status of vegetation cover based on respondents' $(n=100)$ viewpoints in Geraigikh Administrative in Bara Locality, North Kordofan-Sudan. 
Table 1. Trends of vegetation cover based on respondents' $(n=100)$ viewpoints in Geraigikh Administrative in Bara Locality, North Kordofan-Sudan.

\begin{tabular}{|c|c|c|c|c|}
\hline \multirow{3}{*}{ Time } & \multicolumn{4}{|c|}{ Status of vegetation caover } \\
\hline & Very good & Good & Poor & Do not know \\
\hline & \multicolumn{4}{|c|}{ Respondents (\%) } \\
\hline Current & 24 & 36 & 40 & 0 \\
\hline Before 10 years & 31 & 53 & 14 & 2 \\
\hline Before 20 years & 45 & 22 & 27 & 6 \\
\hline Before 30 years & 33 & 7 & 30 & 30 \\
\hline Average & 33.3 & 29.5 & 27.8 & 9.5 \\
\hline
\end{tabular}

'Iable 2. Uccurrence and abundance of some tree/shrubs and trequency of understory species in Geraigikh Administrative in Bara Locality, North Kordofan-Sudan.

\begin{tabular}{|c|c|c|c|c|c|c|c|}
\hline No. & & Tree species & & & & Grass & \\
\hline & Local name & Latin name & $\mathrm{F}(\%)$ & Abundance & Local name & Latin name & $\mathrm{F}(\%)$ \\
\hline 1 & Merekh & Leptadenia pyrotechnica & 85.7 & 35.0 & Gaw & Aristida spp. & 95 \\
\hline 2 & Seyal & Acacia tortilis & 81.0 & 37.8 & Bano & Eragorostis termula & 95 \\
\hline 3 & Higlig & Balanites aegyptiaca & 38.1 & 4.7 & Haskanit & Cenchrus spp. & 67 \\
\hline 4 & Sidr & Ziziphus spina-christi & 33.3 & 6.6 & Umfesaisat & Tripogon minimus & 43 \\
\hline 5 & Haraz & Fedherbida albida & 28.6 & 1.9 & Umageiga & Digitaria velutina & 43 \\
\hline 6 & Hashab & Acacia senegal & 19.0 & 1.2 & Dreisa & Tribulus terrestris & 33 \\
\hline 7 & Dom & Hyphaene thebaica & 19.0 & 9.3 & Ergisi & Chrozophora brochiana & 29 \\
\hline 8 & Laot & Acacia nubica & 0.19 & 2.8 & Tumam & Panicum tirgidum & 19 \\
\hline 9 & Sarha & Maerua crassifolia & 0.10 & 0.2 & Sanamaka & Cassia senna & 14 \\
\hline 10 & Tundub & Capparis deciduas & 0.05 & 0.4 & Rabaa & Trianthema pentandra & 14 \\
\hline 11 & & & & & Hantoot & Ipomoea kotschyana & 10 \\
\hline 12 & & & & & Adanelfar & Indigofera diphylla & 10 \\
\hline
\end{tabular}

same vegetation assessment of GEF (1994). The difference in species abundance could have resulted from the difference in sampling techniques since GEF (1994) classified the area into three ecozones, with different site conditions, while this study the vegetation assessment was conducted regardless of that ecozones. Other reason for the low abundance of tree/shrubs species could be attributed to the resource users (respondents) that prefer a certain tree species for local use e.g. building materials.

\section{Land Cover Distribution and Changes}

Results of the land cover analysis revealed to five classes, these are woody vegetation, Acacia senegal stands, shrubs (Leptadenia pyrotechnca and Acacia nubica) and small scale farms and grasses in addition to sandy soil and dunes (Fig. 3). The results indicated that the rate of change in sandy soil and dunes had increased by $21.72 \%$ from 1985 to 2015 while woody vegetation was increased only by $3.34 \%$ and small scale farms by $2.1 \%$. The other types of vegetation Acacia senegal stands and shrubs were decreased in area by 17.43 and 9.72 percent, respectively (Table $3)$. The increase in woody vegetation by 3.34 percent could be attributed to the community awareness to the importance of tree cover in their livelihood. However, the decreasing trend of shrubs and Acacia senegal stands may be refer to erratic and low quantity of rainfall in the study area. Nevertheless, Figure 4 shows increasing trend of rainfall quantity through 1985 to 2015. This trend may encourage small scale farming, the main livelihood activities (Francis, 2010), to increase which has negative impact on vegetation cover. The increasing rate of sand encroachment at the expense of other land cover 
classes necessitates certain measures since it threats

agricultural farms and livelihood of local population.

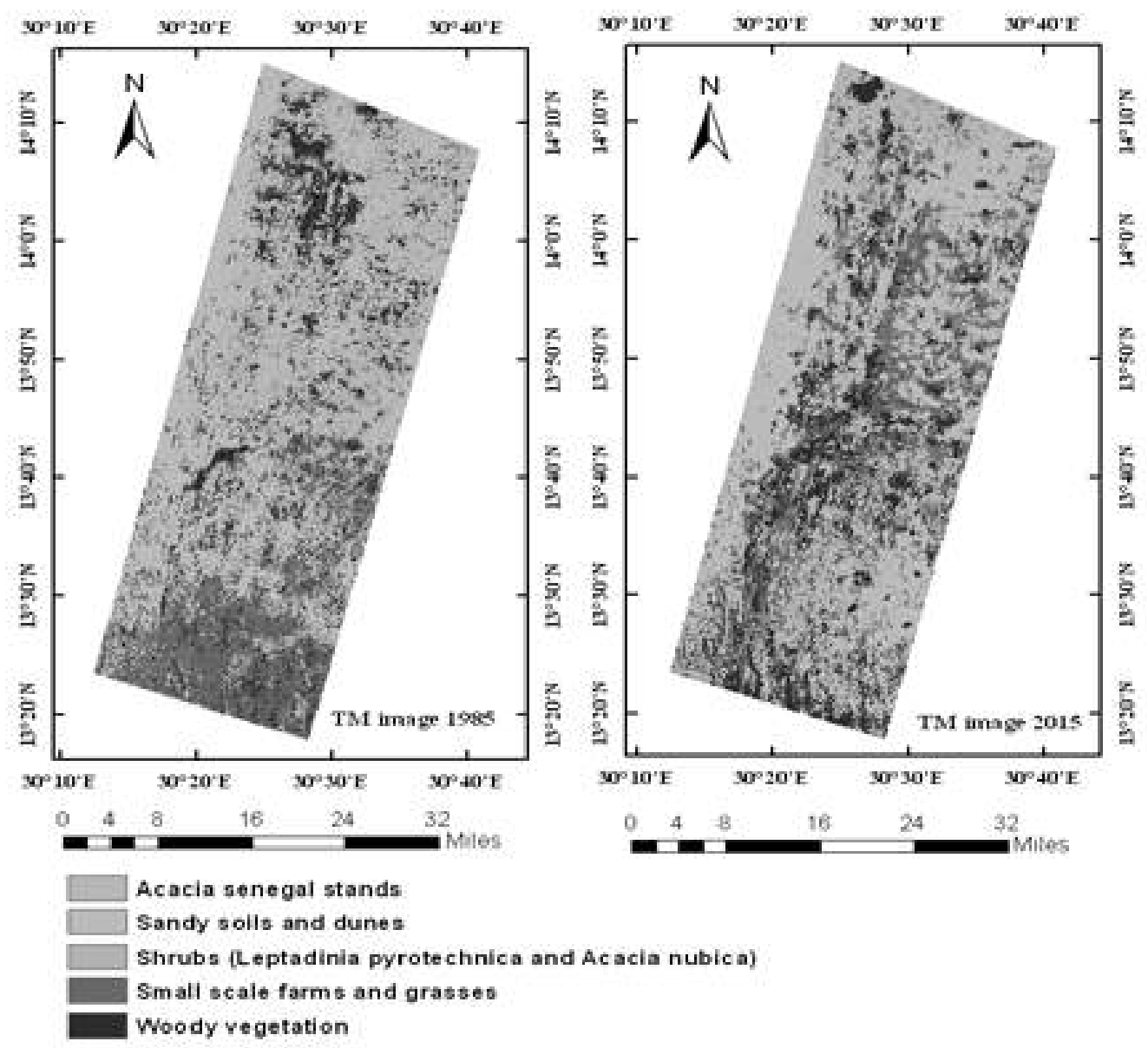

Figure 3. Classified TM imageries showing land use and land cover classes at Geraigikh Administrative in Bara Locality, North Kordofan-Sudan, during 1985-2015.

Table 3. Distribution of land cover classes and rate of changes between 1985 and 2015 in Geraigikh Administrative in Bara Locality, North Kordofan-Sudan.

\begin{tabular}{|c|c|c|c|c|c|}
\hline \multirow{2}{*}{ Land cover class name } & \multicolumn{2}{|c|}{1985} & \multicolumn{2}{|c|}{2015} & \multirow{2}{*}{ Total change $(\%)$} \\
\hline & Area (ha) & $\%$ & Area (ha) & $\%$ & \\
\hline Woody vegetation & 4619.40 & 15.41 & 5620.72 & 18.75 & $(+) 3.34$ \\
\hline Acacia senegal stands & 6640.10 & 22.15 & 1414.10 & 4.72 & $(-) 17.43$ \\
\hline Shrubs ${ }^{*}$ & 8383.98 & 27.97 & 5468.80 & 18.24 & $(-) 9.72$ \\
\hline Small scale farms and grasses & 5194.41 & 17.33 & 5823.16 & 19.42 & $(+) 2.10$ \\
\hline Sandy soils and dunes & 5141.07 & 17.15 & 11652.19 & 38.87 & $(+) 21.72$ \\
\hline Total & 29978.96 & 100.00 & 29978.96 & 100.00 & 0.00 \\
\hline
\end{tabular}

"Shrubs = Leptadinia pyrotechnica and Acacia nubica 


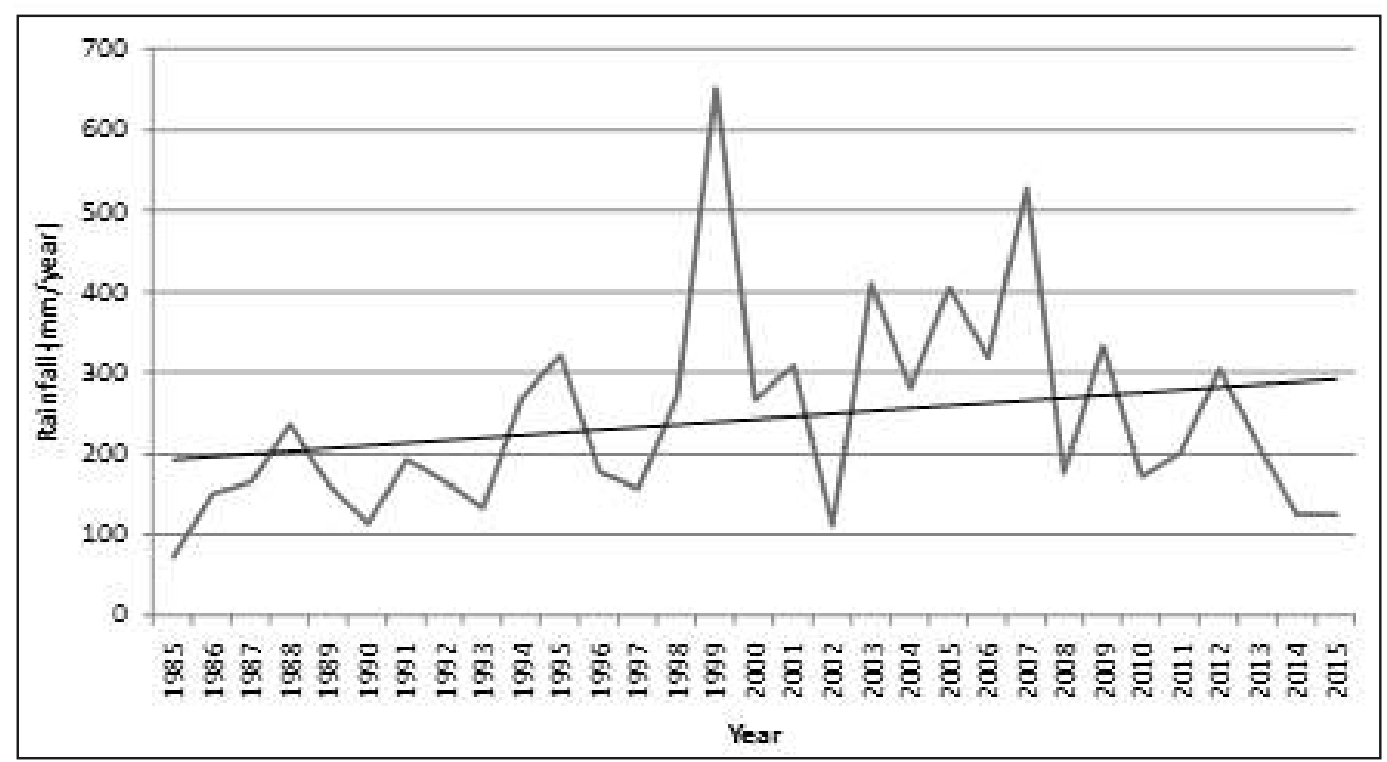

Figure 4. Annual rainfall in Bara Locality, North Kordofan-Sudan (1985-2015).

Source: Agriculture Administration Office, Bara Locality, 2015.

\section{CONCLUSIONS}

In general, the trend in land cover change at Geraigikh area, Bara Locality will continue since the basic driving forces of land cover change are continue. Such factors are for example expansion of farming activities. Results about vegetation quality from social survey are slightly differ from the terrestrial and remote sensing images, that cover the whole study area, because social survey depends on the individual respondent view point about specific area which might be subjective. Nevertheless, the findings of this study indicate the possibility of integrating qualitative data (social survey) and terrestrial one supported by remote sensing techniques in vegetation cover assessment of the dry lands of the Sudan.

\section{ACKNOWLEDGEMENTS}

This paper is part of the results of M.Sc thesis of the second author. Scholarship was secured for the second author by Sudan Academy of Sciences.

\section{REFERENCES}

Adam HE. 2011. Integration of Remote Sensing and GIS in Studying Vegetation Trends and Conditions in the Gum Arabic Belt in North Kordofan Sudan. Rhombas- Verlag, Berlin, Germany.

Agriculture Administration Office. 2015. Agriculture Administration Office, Bara Locality, North Kordofan, Sudan.

Chalmers N \& Fabricius C. 2007. Expert and generalist local knowledge about land-cover change on South Africa's Wild Coast: can local ecological knowledge add value to science? Ecology and Society 12(1), 10.

Elasha BO. 2006. Environmental strategies to increase human resilience to climate change: lessons for Eastern and Northern Africa. A final report submitted to Assessments of Impacts and Adaptations to Climate Change (AIACC), Project No. AF 14. The International START Secretariat, USA.

Elasha BO, Goutbi N, Spanger-Siegfried E, Dougherty B, Hanafi A, Zakieldeen S, Sanjak E, Atti, HA. \& Elhassan HM. 2008. Community development and coping with drought in rural Sudan. In : Leary N, Adejuwon J, Barros V, Burton I, Kulkarni J \& Lasco R. (Eds). Climate Change and Adaptation. EARTHSCAN, London, Sterling, VA. 
Francis A E. 2010. Tree diversity, use and land cover changes in Mt. Otzi Forest Reserve, Northern Uganda. A report submitted to the International Leadership and Capacity Building Bursary (ILCB), Royal Geographical Society. https://www.rgs.org/NR/rdonlyres/4BBC0713-4 749-47FB-84D7-6FFC0E1FFC58/0/Reportform ErikFrancisAcanakwoPDF.pdf. Accessed on Feb. 15, 2016.

Gardner TA. et al. 2013. A social and ecological assessment of tropical land uses at multiple scales: the Sustainable Amazon Network. Phil Trans $R \quad S o c \quad B \quad$ 368: 20120166. http://dx.doi.org/10.1098/rstb.2012.0166.

GEF Global Environment Facility. 1994. Sudan community-based rangeland rehabilitation for carbon sequestration and biodiversity. Project Document, UNDP.

Glover EK. 2005. Tropical dryland rehabilitation: Case study on participatory forest management in Gedaref, Sudan. PhD Academic Dissertation, University of Helsinki.

Godinez-Alvarez, H, Herrick JE, Mattocks M, Toledo D \& Van Zee J. 2009. Comparison of three vegetation monitoring methods : Their relative utility for ecological assessment and monitoring. Ecological Indicators 9,1001-1008.

Huntington HP. 2000. Using traditional ecological knowledge in science: methods and applications. Ecological Applications 10(5), 1270-1274.

Ibrahim RSM. 2013. Assessment of vegetation cover changes during 1986 -2011, using remote sensing technique in Kunduwa Forest, South Darfur State, Sudan. MSc Thesis, Faculty of Forestry, University of Khartoum, Sudan.

IPCC. 2001. Third assessment report of the Intergovernmental Panel on Climate Change. Cambridge University Press, Cambridge.

Kellner K, Risoli C, \& Metz. M. 2011. Terminal evaluation of the UNEP/FAO/GEF Project: Land Degradation Assessment in Drylands (LADA), United Nations Environment Programme.

Khiry MA. 2007. Spectral mixture analysis for monitoring and mapping desertification processes in-semi-arid areas: Applications of remote sensing in monitoring drylands, North Kordofan State- Sudan. PhD Thesis. Institute of Institute of Photogrammetry and Remote Sensing, TU Dresden, German.

Khiry MA, Mahmoud TE, Csaplovics E, Ali HI, \& Khatir AA. 2014. Description and assessment of land cover changes in relation to climatic conditions and socioeconomic activities in semi-arid areas of North Kordofan State, Sudan. University of Kordofan Journal of Natural Resources and Environmental Studies 1(2), 20-38.

Kumar K. 1989. Conducting key informant interviews in developing countries. A.I.D. Program design and evaluation methodology report No. 13. Agency for International Development.

Kumpula T, Forbes BC, Stammler F \& Meschtyb N. 2012. Dynamics of a coupled system: multi-resolution remote sensing in assessing social-ecological responses during 25 years of gas field development in Arctic Russia. Remote Sensing 4, 1046-1068.

Lee W, McGlone M, \& Wright E. 2005. Biodiversity Inventory and Monitoring : A review of national and international systems and a proposed framework for future biodiversity monitoring by the Department of Conservation. Landcare Research Contract Report: LC0405/122.

Mather PM \& Brandt T. 2009. Classification methods for remotely sensed data (2nd Ed.). Taylor and Francis Group, LLC.

Millennium Ecosystem Assessment. 2005. Ecosystems and human well-being: desertification synthesis. World Resources Institute, Washington, DC.

NAPA. 2007. National Adaptation Programme of Action. Republic of the Sudan, Ministry of Environment and Physical Development, Higher Council for Environment and Natura Resources, Khartoum.

Sillivan S \& Rode R. 2002. On non-equilibrium in arid and semi-arid grazing systems. Journal of Biogeography 29, 1595-1618.

Squires V R. 2010. The subset of UNCCD impact indicators - Land Cover Status. Consultancy report prepared for the UNCCD. http://www.unccd.int/en/programmes/Science/M onitoring-Assessment/Documents/Report_LandCover-Status.pdf. Accessed on November 16, 2015.

Wallace W \& Furby S. 1994. Assessment of Change in Remnant Vegetation Area and Condition. A report from the LWRRDC project: Detecting and Monitoring Changes in Land Condition Through Time using Remotely Sensed Data. CSIRO Mathematical and Information Sciences, Agriculture Western Australia. 